\title{
Incidental choledochocoele, imaging and endoscopic findings
}

\author{
Mavis Orizu, Kevin Robertson
}

University Hospital Crosshouse, Kilmarnock, UK

\section{Correspondence to}

Mavis Orizu, morizu@nhs.net

Accepted 21 April 2016

\section{DESCRIPTION}

A 70-year-old man being investigated for weight loss was found to have an incidental cystic lesion at the level of the ampulla with a normal extrahepatic biliary tree on CT. Liver function tests were normal. MR cholangiopancreatography suggested a focal dilation of the common bile duct deemed proximal to the ampulla, suspicious for malignancy with post-stenotic dilation (figure 1). At endoscopic retrograde cholangiopancreatography, it was seen

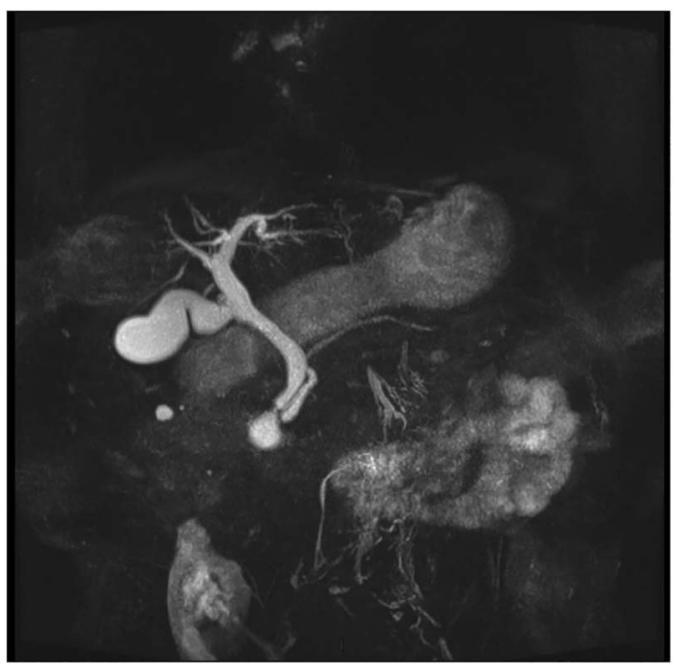

Figure 1 MRCP image showing focal dilation of the distal common bile duct. MRCP, MR cholangiopancreatography.

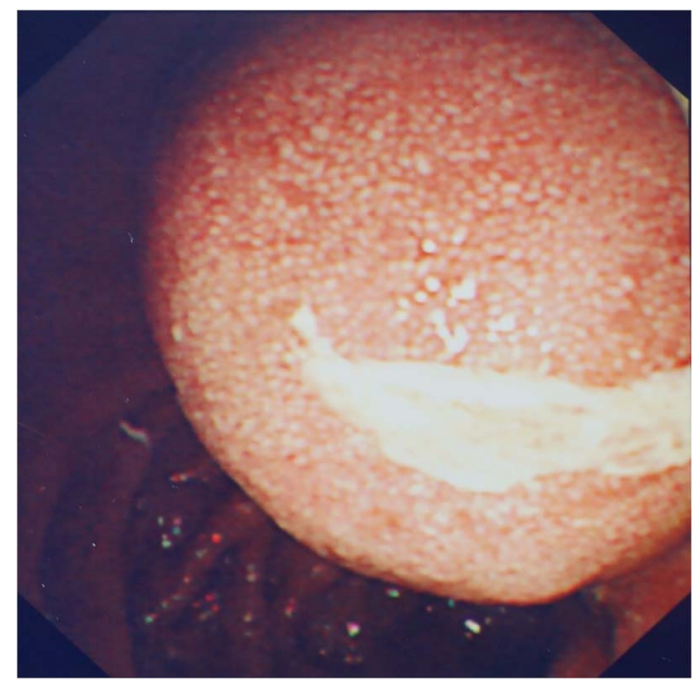

Figure 2 ERCP revealing an intraluminal bulge into the second part of the duodenum. ERCP, endoscopic retrograde cholangiopancreatography.

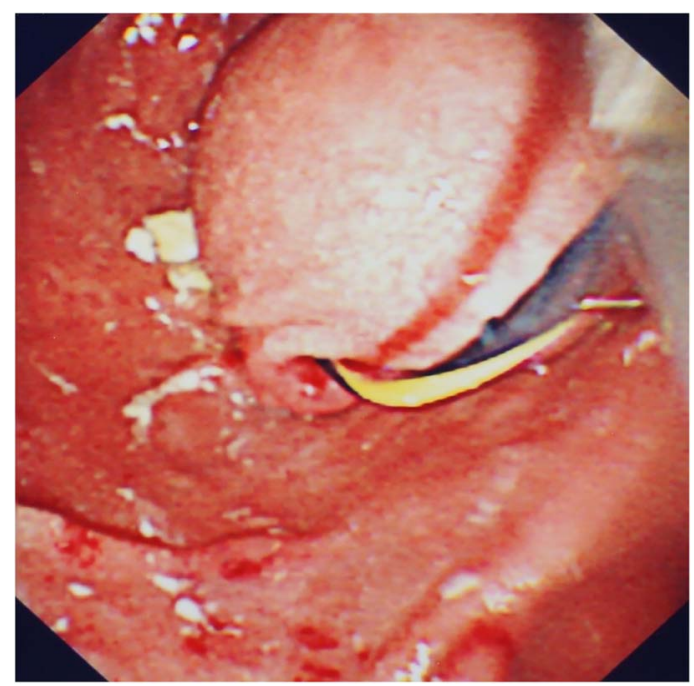

Figure 3 The ampulla was located at the lower end of this lesion and cannulated with a guidewire.

to be a bulge into the duodenum (figure 2), through which the ampulla was cannulated with a guidewire (figure 3). Biliary and pancreatic duct anatomy was seen on cholangiography (figure 4). This was in keeping with a choledochocoele. Bile duct brushings were negative for malignancy on cytology and the patient subsequently underwent endoscopic sphincterotomy with release of multiple stones; he made an uneventful recovery.

A choledochocoele (or type III choledochal cyst $)^{1}$ is a rare congenital malformation in which

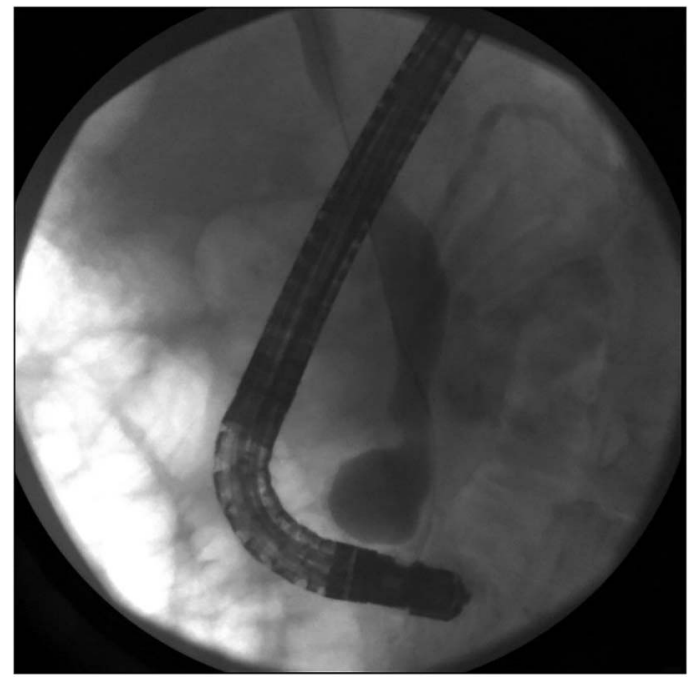

Figure 4 Cholangiogram showing the guidewire in the common bile duct, which is dilated intraduodenally. The pancreatic duct is outlined in the top right of the image. 
there is a cystic dilation of the intraduodenal portion of the distal common bile duct. They are often a cause for recurrent right upper quadrant pain, jaundice or hyperamylasaemia. They may be associated with cholangitis, choledocholithiasis and

\section{Learning points}

- Choledochocoele is a rare congenital malformation of the common bile duct that can harbour gallstones.

- It is usually benign but radiological appearance may be concerning for malignancy although malignant transformation is rare.

- Small choledochocoeles can often be managed endoscopically. acute pancreatitis; malignant transformation is a rare occurrence. ${ }^{2}$ Most choledochocoeles may be managed by endoscopic sphincterotomy or snare resection, but surgical excision may be indicated with more complex anatomy or suspicion of malignancy. ${ }^{3}$

Competing interests None declared.

Patient consent Obtained.

Provenance and peer review Not commissioned; externally peer reviewed.

\section{REFERENCES}

1 Todani T, Watanabe Y, Narusue M, et al. Congenital bile duct cysts. Am J Surg 1977;134:263-9.

2 Soares KC, Arnaoutakis DJ, Kamel I, et al. Choledochal cysts: presentation, clinical differentiation, and management. J Am Coll Surg 2014;219:1167-80.

3 Law R, Topazian M. Diagnosis and treatment of choledochoceles. Clin Gastroenterol Hepatol 2014;12:196-203.

Copyright 2016 BMJ Publishing Group. All rights reserved. For permission to reuse any of this content visit http://group.bmj.com/group/rights-licensing/permissions.

BMJ Case Report Fellows may re-use this article for personal use and teaching without any further permission.

Become a Fellow of BMJ Case Reports today and you can:

- Submit as many cases as you like

- Enjoy fast sympathetic peer review and rapid publication of accepted articles

- Access all the published articles

- Re-use any of the published material for personal use and teaching without further permission

For information on Institutional Fellowships contact consortiasales@bmjgroup.com

Visit casereports.bmj.com for more articles like this and to become a Fellow 